1976). As about 4 kilometres of sediments are missing on the upthrown block to the west of the fault, this block must have been exposed for a considerable time.

\title{
References
}

Bishop, R. S. 1978: Mechanism for emplacement of piercement diapirs. Bull. Am. Ass. Petrol. Geol. 62, 1561-1583.

Clarke, D. B. \& Pedersen, A. K. 1976: Tertiary volcanic province of West Greenland. In Escher, A. \& Watt, W. S. (edit.) Geology of Greenland, 364-385. Copenhagen: Geol. Surv. Greenland.

Geological Survey of Greenland 1978: Well data summary sheets. August 1978. Kangâmiut 1.

Henderson, G. 1978: Developments in petroleum exploration offshore West Greenland during 1977. Rapp. Grønlands geol. Unders. 90, 32-36.

\section{Project WESTMAR - A shallow marine geophysical survey on the West Greenland continental shelf between latitudes $64^{\circ}$ and $70^{\circ} \mathrm{N}$}

\author{
Colin P. Brett and Edward F. K. Zarudzki
}

Project WESTMAR is designed to provide detailed knowledge of the geological and geotechnical properties of the sea-floor and shallow sub-surface with particular reference to the exploration and development of any hydrocarbon resources in the area, as part of an energy-related research programme sponsored by the Danish Ministry for Commerce. An extensive shallow marine geophysical survey was undertaken during June and July 1978 on the West Greenland continental shelf in the region $64^{\circ}-70^{\circ} \mathrm{N}$ (fig. 20). Approximately 8000 line $\mathrm{km}$ of sparker seismic, magnetic and bathymetric data were acquired together with 4000 line $\mathrm{km}$ of side-scan soner/sub-bottom profiler data. Accurate and continuous position fixing was achieved with an integrated satnav/doppler sonar navigation system. A preliminary interpretation of the data is presented in a separate report (Brett \& Zarudzki, 1979).

\section{Reference}

Brett, C.P. \& Zarudzki, E. F. K. 1979: Project Westmar - A shallow marine geophysical survey on the West Greenland continental shelf. Rapp. Grønlands geol. Unders. 87, 29 pp. 


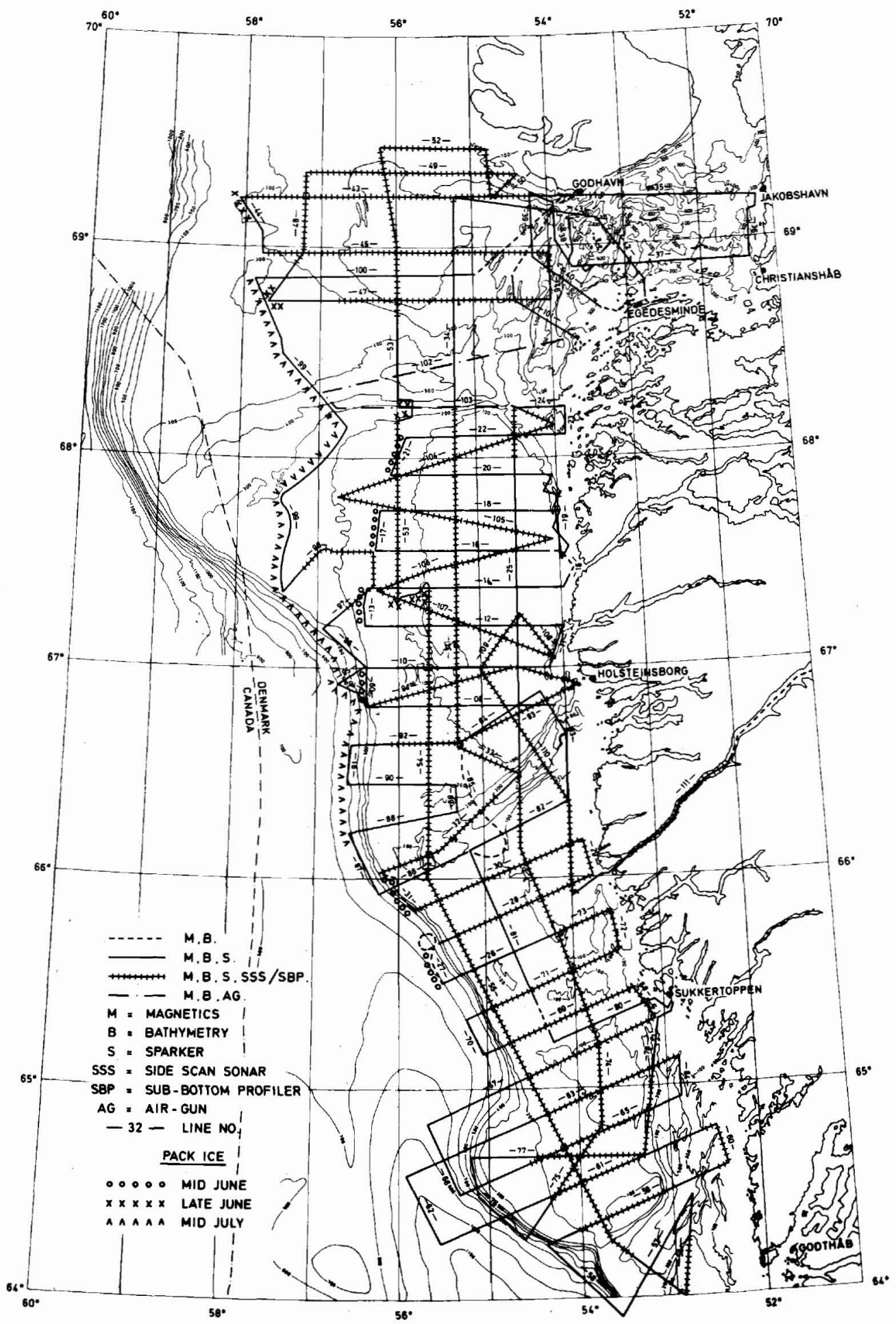

Fig. 20. Track chart of project WESTMAR cruise 1978. 